\title{
Klass i begåvningsreservens tidevarv: Taxonomiska konflikter inom och genom svensk utbildningsforskning, ca 1945-1960
}

\author{
Carl-Filip Smedberg
}

\begin{abstract}
Class in the age of the pool of talent: Taxonomic struggles in and through Swedish education research, c. 1945-1960. This article studies conceptualisations of social class in Swedish education research, c. 1945-1960. The article follows knowledge produced about talent and class in state commissions and in the newly expanded social sciences, and how it in turn was interpreted and used in political debates and in the media. I show that the taxonomy of the population in social groups (Socialgrupper) was key for conceptualising notions of talent and framing education policy, beginning with debates around "the pool of talent" (Begåvningsreserven) in 1948. At the same time as becoming a standard tool for mapping social difference in Sweden, the social group taxonomy was criticised for being unscientific.
\end{abstract}

Keywords • Post-war Sweden [efterkrigstidens Sverige], history of the education sciences [utbildningsvetenskapernas historia], social group [socialgrupp], social class [samhällsklass]

\section{Produktiva klasstaxonomier}

År 1948 presenterade den socialdemokratiska politikern Ragnar Edenman (19141998) en statlig utredning som visade att endast några få procent av Sveriges studenter kom ifrån "socialgrupp III". Edenman lanserade det snart mycket populära begreppet begåvningsreserven för att peka ut detta samhälleliga slöseri. ${ }^{1}$ Socialgruppssifforna åskådliggjorde enligt svensk press hur utbildningssektorn stått utanför resten av samhällets demokratisering. ${ }^{2}$ Utredningen argumenterade i sitt betänkande att skillnaderna inte kunde försvaras - landet gjorde sig skyldig till "ett uppenbart

1 Osignerad artikel, "Sverige kan producera ytterligare 8.000 studenter pr år," Aftonbladet, 17 mars, 1948a; SOU 1948:42, Betänkande och förslag angående studentsociala stödåtgärder (Stockholm: Katalog och tidskriftstryck, 1948). I historieskrivningen framhävs Ragnar Edenman som upphovsman till termen "begåvningsreserv", se exempelvis Torsten Husén och Kjell Härnqvist, Begåvningsreserven: En återblick på ett halvsekels forskning och debatt (Uppsala: Föreningen för svensk undervisningshistoria, 2000), 34; Gunnar Richardson, Drömmen om en ny skola: Idéer och realiteter $i$ svensk skolpolitik 1945-1950 (Stockholm: Liber/Allmänna förlaget, 1983), 344; Hanna Markusson Winkvist, "Perspektiv på begåvningsreserven," Lychnos (2014), 122. Han gjorde helt klart begreppet populärt, men termen återfinns dock tidigare, se exempelvis Erik Wellander, "Det nya gymnasiets bildningsvärde," Svenska Dagbladet, 20 juli, 1932.

2 Allan Fagerström, "De odemokratiska akademierna," Aftonbladet, 20 mars, 1948. Se också Osignerad artikel, "De rikas universitet," Arbetartidningen, 22 oktober, 1948; Osignerad artikel, "Universiteten öppnas," Aftonbladet, 5 november, 1948b; Osignerad artikel, "Var 4:e student... Begåvningsreserven ur lägsta socialgruppen bör släppas fram till universitetsbildning," Dagens Nyheter, 6 november, 1948; Osignerad artikel, "Vår begåvningsreserv måste utnyttjas för högre studier," Svenska Dagbladet, 6 november, 1948.

Carl-Filip Smedberg is a Doctoral Student at the Department of History of Science and Ideas, Uppsala University, Sweden.

Email: carl-filip.smedberg@idehist.uu.se 
slöseri med vårt lands teoretiska begåvningar" - "den största nationella tillgången." "Siffrorna är groteska", skrev en av utredarna i den socialdemokratiska idétidskriften Tiden: de gav bilden av "ett reaktionärt och efterblivet land." ${ }^{4}$ Begåvning upprättades här som en gemensam angelägenhet att på olika sätt främja för samhällets väl, och som en rättvisefråga för den enskilde som hållits tillbaka från sin potential.

Utbildningshistorisk forskning har visat på ett utbildningspolitiskt skifte under efterkrigstiden. Ett nytt perspektiv öppnade upp sig där utbildning och forskning, speciellt natur- och teknikvetenskaperna, kom att ses som en produktiv faktor att inventera och kultivera för att nå ökat samhälleligt välstånd. ${ }^{5}$ Skolan blev en viktig plats för att förändra samhällets normer. Barnen skulle nu fostras in i ett demokratiskt sinnelag. ${ }^{6}$ Med begåvningsreservsdebatten förändrades synen på högre utbildning som förbehållen en liten elit mot uppfattningen att en allt större del av befolkningen hade anlag att studera. ${ }^{7}$ En gemensam nioårig enhetsskola, ett nytt sammanhållet gymnasiesystem och ett högskolesystem dimensionerat för en allt större andel av varje årskull skapades senare som följd. Historikern Lina Carls har i sin tur undersökt diskursen kring begåvningsreserven och högre utbildning ur ett genusperspektiv och pekat på hur utbyggnaden av högskolan främst skedde med den manliga delen av befolkningen i åtanke. ${ }^{8}$

Underutvecklat i tidigare forskning är dock den begreppsliga konceptualiseringen av klass och bruket av statistiska kategorier inom utbildningssektorn. Inledningsexemplen signalerar hur centralt indelningen av befolkningen i socialgrupper var, både för begåvningsreservsbegreppet och för diskussionen om utbildning i Sverige i stort. Historiker har framhållit hur diskussionen om intelligens, från att tidigare handlat om skillnader mellan raser och klasser, kom att $\mathrm{i}$ allt högre grad individualiseras i 1950-talets USA, i kontrast till Storbritannien där klass förblev en viktig faktor inom utbildningsforskningen..$^{9}$ Men även inom detta internationella forskningsläge

3 Betänkande och förslag angående studentsociala stödåtgärder (1948), 14-16.

4 Nils Norman, "Demokratiseringen av de akademiska yrkena," Tiden 39, no. 9 (1947), 546. Se även Per Eckerberg, "Utbildningens demokratisering," Tiden 40, no. 10 (1948); Ingrid Hammarström, "I stället för Långtidsprogram: Kring studentsociala utredningen," Libertas 9, no. 1 (1949); Lars Grafström, "Staten, akademikerna och friheten," Liberal Debatt 1, no. 1 (1948). Vid Sveriges Socialdemokratiska Arbetareparti, Protokoll, Sveriges socialdemokratiska arbetarpartis 18:e kongress i sth. 1948, 9-14 maj (Stockholm: Partiet, 1948), 97-99, diskuterade Edenman och Tage Erlander statistiken.

5 Floran Waldow, Utbildningspolitik, ekonomi och internationella utbildningstrender i Sverige 19302000 (Stockholm: Stockholms universitets förlag, 2008), 179; Markusson Winkvist (2014), 110-12; Daniel Lövheim, Naturvetarna, ingenjörerna och valfrihetens samhälle: Rekrytering till teknik och naturvetenskap under svensk efterkrigstid (Lund: Nordic Academic Press, 2016).

6 Johan Östling, Nazismens sensmoral: Svenska erfarenheter i andra världskrigets efterdyning (Stockholm: Atlantis, 2008); Jonas Qvarsebo, "Fabricating and Governing the Swedish School Pupil: The Swedish Post-War School Reform and Changing Discourses of Discipline and Behaviour," Nordic Journal of Educational History 5, no. 2 (2018), 111-30.

7 Richardson (1983), 247.

8 Lina Carls, Våp eller nucka? Kvinnors högre studier och genusdiskursen 1930-1970 (Lund: Nordic Academic Press, 2004), 180-235.

9 Jim Porter, "A 'Precious Minority': Constructing the 'Gifted' and 'Academically Talented' Student in the Era of Brown v. Board of Education and the National Defense Education Act," Isis 108, no. 3 (2017); Adrian Wooldridge, Measuring the Mind: Education and Psychology in England, c. $1860-c$. 1990 (Cambridge: Cambridge University Press, cop., 1994), 270-81. 
är klasskonceptualiseringar inte särskilt studerade. ${ }^{10}$

Syftet med denna artikel är att analysera klasskategoriernas roll inom svensk utbildningsforskning under efterkrigstid. Mer preciserat: hur användes socialgruppsindelningen i utbildningsforskning åren 1945-1960, och hur brukades kunskapen denna gav upphov till i media och i den politiska samhällsdebatten? Socialgruppsindelningen var särskilt central i begåvningsreservsdebatten, men fokus är inte begränsat till detta exempel. Istället är statistiska klasskategorier, genom socialgruppstaxonomin, huvudsak. Material för undersökningen har jag fătt fram genom systematiska sökningar på socialgrupp* i KB:s databas över svenska digitaliserade dagstidningar samt i Linköping universitets databas över digitaliserade statliga utredningar, såväl som med hjälp av genomläsningar av samhällsvetenskaplig forskning och idépolitiska tidskrifter från perioden. ${ }^{11}$ Artikeln börjar med en diskussion om socialgruppsindelningens roll inom utbildningsforskningen, för att sedan studera hur denna kunskap kom att användas i media och inom politisk debatt.

Utöver en utbildningshistorisk forskningsfront bidrar denna artikel till forskning om klass ur ett kulturhistoriskt perspektiv. Historiker har inom detta fält undersökt aktörers empiriska begreppsliggöranden av klass: kategoriernas framväxt, formering, samt politiska och kulturella genomslag. ${ }^{12}$ Några har här studerat hur samhällsvetenskaplig forskning aktivt skapat och format populära klassförståelser. ${ }^{13}$ Jag följer dessa sätt att analysera klasskategorier som sammanlänkade med olika former av expertis och kunskapsproduktion. Studier under 1960- och 70-talen slog fast att de flesta svenskar kunde, om tillfrågade, placera in sig själva i en socialgrupp. ${ }^{14}$ En arbetsgrupp på Statistiska centralbyrån (SCB) framhöll att "denna indelning har i vårt land slagit igenom så helt, att många tycks vara böjda att anse det mer eller mindre självklart, att det är meningsfullt att indela... den nutida svenska befolkningen i socialgrupperna 1, 2 och 3." ${ }^{15}$ En viktig orsak till detta genomslag är, som jag kommer att visa, den storskaliga kunskapsproduktionen kring socialgrupperna i välfärds- och utbildningsforskningen som växte fram efter andra världskriget inom kommittéväsendet och i discipliner som sociologi, psykologi, och pedagogik.

10 Se dock Chris Renwick, "Eugenics, Population Research, and Social Mobility Studies in Early and Mid-Twentieth-Century Britain," The Historical Journal 59, no. 3 (2016); Chris Renwick, "Movement, Space and Social Mobility in Early and Mid-Twentieth-Century Britain," Cultural and Social History 16, no. 1 (2019).

11 Tidskrifterna är Tiden, Svensk Tidskrift, Liberal Debatt, Libertas, Svensk Linje, samt Samtid och Framtid.

12 Se exempelvis Gareth Stedman Jones, Languages of Class: Studies in English Working Class History, 1832-1982 (Cambridge: Cambridge University Press, 1984); Patrick Joyce, Visions of the People: Industrial England and the Question of Class, 1848-1914 (Cambridge: Cambridge University Press, 1991), Ulrika Holgersson, Klass: Feministiska och kulturanalytiska perspektiv (Lund: Studentlitteratur, 2011).

13 Sheila Fitzpatrick, "Ascribing Class: The Construction of Social Identity in Soviet Russia," Journal of Modern History 65, no. 4 (1993); Mike Savage, Identities and Social Change in Britain Since 1940: The Politics of Method (Oxford: Oxford University Press, 2010), 6-10; Jon Lawrence, "Social-Science Encounters and the Negotiation of Difference in early 1960s England," History Workshop Journal, 77, no. 1 (2014).

14 Gösta Carlsson et al., "Socio-ekonomiska grupperingar," Statistisk Tidskrift 12, no. 5 (1974), 381.

15 Statistiska Centralbyrån, Sociala grupper i svensk statistik: Ett förslag framlagt av en av Statistiska centralbyrån tillsatt arbetsgrupp (Stockholm: SCB, 1967), 3. 
Teoretiskt perspektiv i artikeln kommer från statistikhistorisk forskning och statistiksociologi. Theodore Porter framhåller i ett inflytelserikt verk att statistik historiskt har använts för att etablera auktoritetspositioner i olika frågor, då de ger skenet av vad Porter kallar mekanisk objektivitet, utsagor fria från personligt omdöme. ${ }^{16}$ Vetenskapsfilosofen Ian Hacking betonar istället statistiska kategoriers sätt att "skapa" vad de beskriver, genom att människor börjar använda dem för att beskriva världen och sig själva. De är produktiva. ${ }^{17}$ Vad dessa två forskare delar är dock ett sätt att skildra kategorier i administrativ statistikproduktion som att de blir "black boxed", stabila och ytterst svåra att utmana för utomstående, när de väl etablerats. ${ }^{18}$ Statistiksociologi betonar i sin tur de effekter kvantifiering och skilda kvantitativa mått får på kunskapsobjekt. Statistik reducerar komplexitet hos kategorier, när skilda kvalitéer och variabler integreras till en siffra. Detta reduceringsarbete möjliggör för aktörer att enklare representera och jämföra skillnader. ${ }^{19}$

\section{Den pedagogiska produktionen av skillnad: Socialgruppsindelningen inom svensk utbildningsforskning}

Socialgruppsindelningen uppkom redan 1911 inom SCB i syfte att övervaka i vilken grad de olika samhällsklasserna använde sin rösträtt. Socialgrupp I bestod av större företagare, akademiker, fria yrken, samt högre tjänstemän, socialgrupp II sammanförde lägre tjänstemän, köpmän, hantverkare och bönder, medan socialgrupp III utgjordes av kroppsarbetare av olika slag. Rationaliteten bakom förklarades aldrig, förutom att indelningen gått efter en "social" bedömning, där faktorer som allmän yrkesstatus, inkomst, och utbildningsnivå sammanslagits. ${ }^{20}$ Sociologen Rosemary Crompton beskriver liknande klassindelningar efter yrkestillhörighet och status som att vara deskriptiva - vanliga i efterkrigstidens statliga administration och sociologiska vetenskap - till skillnad från teoretiskt förankrade taxonomier där det finns ett anspråk på att förklara den sociala skiktningen. ${ }^{21} 1948$ publicerade SCB valstatistik strukturerad genom socialgruppstaxonomin för sista gången. ${ }^{22}$ I interna dokument kallades gränsdragningen mellan socialgrupperna godtycklig. Skillnaderna i röstning mellan yrkesgrupperna inom socialgrupperna var så olika att medeltalen för hela socialgruppen blev missvisande. De sökte därför en "invändningsfri definition

16 Theodore Porter, Trust in Numbers: The Pursuit of Objectivity in Science and Public Life (Princeton: Princeton University Press, 1995).

17 Ian Hacking, The Taming of Chance (Cambridge, 1990), 6.

18 Hacking (1990), 3; Porter (1995), 42. Se liknande i Geoffrey C. Bowker och Susan Leigh Star, Sorting Things Out: Classification and its Consequences (Cambridge, Mass.: MIT Press, cop. 1999), 225.

19 Wendy Nelson Espeland och Mitchell L. Stevens, "Commensuration as a Social Process," Annual Review of Sociology 24, no. 1 (1998), 315-16. För en överblick av detta framväxande sociologiska fält, se Rainer Diaz-Bone och Emmanuel Didier, "Introduction: The Sociology of Quantification Perspectives on an Emerging Field in the Social Sciences," Historical Social Research / Historische Sozialforschung 41, no. 2 (2016).

20 Statistiska Centralbyrån, Riksdagsmannavalen åren 1908-1911 (Stockholm: Statistiska Centralbyrån, 1912), 28-31.

21 Rosemary Crompton, Class and Stratification: An Introduction to Current Debates (Malden, MA.: Blackwell, cop., 1998), 54-60.

22 Statistiska Centralbyrån, Riksdagsmannavalen åren 1949-1952 (Stockholm: Statistiska Centralbyrån, 1953), 61. 
av en grupp." ${ }^{23}$ Men samtidigt som SCB övergav indelningen fick den nytt liv. Den blev en central del i många samhällsvetares kartläggningar av det välfärdssamhälle som nu växte fram.

En första storskalig kartläggning av studenternas sociala bakgrund hade skett i mitten av 1930-talet: en statlig kommission, tillsatt 1933 i syfte att studera den enligt samtiden oroväckande ökningen av universitetsstudenter, kom fram till att rekryteringen till universitetet var högst olika mätt med en taxonomi i åtta yrkesklasser. ${ }^{24} \mathrm{I}$ dagstidningarnas respons på utredningen var det statistiken om studenternas ekonomiska ställning under sin studenttid, utgifter, stipendiemöjligheter, och boendesituation, som togs upp för politisk diskussion. Siffror över studenternas härkomst nämns inte. ${ }^{25}$ Man kan spekulera att en sådan kvantifiering av social tillhörighet aldrig slog medialt på grund av svårigheten att på ett pedagogiskt sätt förklara mängden av kategorier för läsarna. Därtill sågs teoretisk begåvning under denna tid som något ytterst sällsynt, och det var dessutom egenskaper som menades gå i arv, något som kan förklara den uteblivna reaktionen. Från tidigt 1900-tal hade en doxa växt fram bland psykologer och pedagoger i Europa och USA som vidhöll att intelligens var någonting entydigt och definierbart inom varje människa. Åsikten att begåvningen var genetiskt överförbar, eller miljöbetingad uppkommen ytterst tidigt hos barnet, delades av de flesta experterna. ${ }^{26}$ Detta anslöt sig även reformister från hela det ideologiska spektrumet till under mellankrigstiden. Vad dessa olika läger delade var ett synsätt att endast en liten elit ansågs predestinerade för högre utbildning. Rättviseaspekten var här att finna dessa utvalda. ${ }^{27}$ Således var debatten om rekryteringen till högre studier i början av 1940-talet påfallande blygsam, enligt historikern Gunnar Richardson. Frågan diskuterades exempelvis sällan i socialdemokratisk press. Tillgången till högre utbildning, om den problematiserades, framställdes som en geografisk fråga - svårigheten för landsbygdsbarn att vidareutbilda sig - inte en klassfråga. Här var statistik om ojämlikhet mellan stad och landsbygd viktigare. ${ }^{28}$

23 "P.M. angående den i de valstatistiska berättelserna använda fördelningen på yrkes- och socialgrupper," Handlingar ordnade efter ämne: Instruktioner, koder, PM. MM., Valstatistikens ämbetsarkiv 1872-1957, Statistiska Centralbyrån, Riksarkivet.

24 Dessa var lantbrukare, folkskollärare, akademiker, direktörer och grosshandlare, affärsmän och köpman, högre tjänstemän, lägre tjänstemän, hantverkare och arbetare. SOU 1936:34, Utredning rörande de svenska universitets- och högskolestudenternas sociala och ekonomiska förhållanden: Bilaga till Betänkande med undersökningar och förslag i anledning av tillströmningen till de intellektuella yrkena (Stockholm: Håkan Ohlssons boktryckeri, 1936), 51. Utredningen har kallats för "den första kvalificerade sammanställningen av statistik om den högre utbildningens omfattning" i Sverige: Rune Premfors, Svensk forskningspolitik (Lund: Studentlitteratur, 1986), 11.

25 Se exempelvis Osignerad artikel, "Studenterna få ofta biinkomster under studierna," Dagens Nyheter, 27 december, 1933; Osignerad artikel, "Fler intellektuella i samhällets tjänst," Aftonbladet, 14 november, 1935; Osignerad artikel, "De intellektuellas yrkesproblem," Svenska Dagbladet, 15 november, 1935.

26 John Carson, The Measure of Merit: Talents, Intelligence, and Inequality in the French and American Republics, 1750-1940 (Princeton: Princeton University Press, cop. 2007), 262.

27 Wooldridge (1994), Kap. 7. För Sverige, se exempelvis den elitistiska liberalen och filosofen Alf Nyman, Bildning, elit, massa: Sju kulturpolitiska kapitel (Stockholm: Hugo Gebers, 1946); Bondeförbundaren Sten Wahlund, "Demokrati och utbildning," Social årsbok (1942), 8; Socialdemokraten Jörgen Westerståhl, "Demokratins skola," Tiden 33, no. 8 (1941).

28 Gunnar Richardsson, Svensk skolpolitik 1940-1945: Idéer och realiteter i pedagogisk debatt och politiskt handlande (Stockholm: Liber Förlag, 1978), 134. 
En av dem som utmanade detta var samhällsvetaren Torsten Husén (19162009). Han hade rekryterats av armén för att få igång intelligenstestningar av de värnpliktiga vid den nystartade Centrala Värnpliktbyrån 1942. Här kan man urskilja hur en av kontexterna till begåvningsreservsbegreppet var just militär metaforik: urskiljandet av potentialitet bland nationens manskap och material. Testerna var menade att sortera ut de svagsinta, urskilja de högbegåvade för officersutbildning, samt uppnå en jämn intelligensblandning inom stridsenheterna. ${ }^{29}$ Men en bieffekt var att ett stort empiriskt material ackumulerades över den manliga delen av befolkningen, med möjligheterna till jämförelser mellan skolbetyg, intelligens, och social bakgrund. I tidskriften Skola och samhälle 1946 beräknade Husén med hjälp av detta empiriska material att långt fler än nuvarande nivåer hade intelligenskapaciteten att kunna klara av realexamen respektive studentexamen. ${ }^{30}$

Året efter vände Husén sig till att studera de sociala komponenterna av intelligens efter att ha kommit i kontakt med en annan ung samhällsvetare, Gunnar Boalt (1910-2000). ${ }^{31}$ Genom att följa en hel skolgeneration i Stockholm argumenterade Boalt i sin avhandling Skolutbildning och skolresultat för barn ur olika samhällsgrupper i Stockholm (1947) att han statistiskt kunde visa på det "sociala handikappet" många elever besatt vid varje ny övergång till en högre skola. Inte bara erhöll socialgrupp I och II högre betyg - något Boalt trodde med säkerhet var miljöbetingat socialgrupp III utgallrades också desto hårdare vid varje ny övergång till högre skola även när eleven hade samma betyg som barn ur andra socialgrupper. Att just SCB:s klasstaxonomi användes kommenterades inte, förutom just att den var från valstatistiken. ${ }^{32}$ Husén gjorde nu en egen studie där han studerade hur social bakgrund korrelerade med utbildningsnivå och intelligens. Husén var kritisk mot socialgruppsindelningen, av skäl vi ska komma till, och delade istället in sitt material efter en taxonomi i fyra grupper skapad av en före detta kollega till honom, Siver Hallgren. Denna hade för en studie av Malmös skolelever korrelerat intelligens, betyg och social bakgrund. Hallgrens indelning liknade SCB:s, förutom att arbetarna uppdelades i två grupper, yrkesskickliga och ej yrkesskickliga arbetare. Dessutom hade familjer över en viss inkomst för "sin" klass flyttats upp en nivå i skalan för att få mer homogenitet. Hallgren var ovanligt öppen i sin diskussion om rationaliteten bakom sin taxonomi: många grupper gav större homogenitet inom enheterna men mindre överblickbarhet, och vice versa. Han sökte därför en "medelväg" med fyra klasser. Hallgren medgav att klasserna hade kunnat göras annorlunda, och vissa barn platsade säkerligen också i närliggande klasser, men huvudsaken var "att skillnaden mellan grupperna är tydlig och odiskutabel." ${ }^{33}$ Denna indelning tyckte Husén var något bättre, mer välmotiverad i sin konstruktion, än SCB:s. Förvirrande nog benämnde

29 Torsten Husén, "Intelligenskrav på olika skolutbildningsstadier: Några resultat från grupptestningar av en årsklass värnpliktiga," Skola och Samhälle 27, (1946), 2-5.

30 Husén (1946), 20-23. Se också Torsten Husén, "Begåvningsurvalet och de högre skolorna," Sydsvenska Dagbladet, 11 maj, 1946.

31 Torsten Husén, En obotlig akademiker: En professors memoarer (Stockholm: Natur och kultur, 1981), 53.

32 Gunnar Boalt, Skolutbildning och skolresultat för barn ur olika samhällsgrupper i Stockholm (Stockholm: Nordstedt, 1947).

33 Siver Hallgren, "Intelligens och social miljö," i Studier i människokunskap tillägnade John Landquist den 3 december 1946 (Lund, Gleerup, 1946), 129. 
han båda indelningarna som "socialgrupper". Husén fann liksom Boalt stora begåvningsreserver just bland de lägre socialgrupperna. ${ }^{34}$

Studentsociala utredningen, med Edenman som ordförande, inkluderade en parallell kartläggning av studenterna efter den indelning i åtta yrkesklasser som skapats inom ramen för 1930-talet universitetskommitté, för att kunna göra jämförelser. Men det var Edenmans presentation av socialgruppssifforna, efter SCB:s taxonomi i tre socialgrupper, tillsammans med begreppet begåvningsreserv, som skapade uppmärksamhet i frågan. Denna indelning motiverades endast med att den tillhörde den "officiella valstatistiken". ${ }^{35}$ Det var det klasschemat som fångade den mediala och politiska fantasin, genom sin pedagogiska enkelhet, och genom att socialdemokraterna enkelt kunde översätta en av klassifikationerna, socialgrupp III, till att vara jämförbar med rörelsens föreställda politiska subjekt, arbetarklassen.

Under efterkrigstiden började samtidigt många andra samhällsvetenskapliga studier bruka SCB:s socialgruppsindelning för att kartlägga sociala skillnader mellan svenskarna ifråga om beteenden, attityder, och livsmönster. Statsvetaren Jörgen Westerståhl (1916-2006) beskrev i början av 1950-talet en i hans ögon ond cirkel social forskning hamnat $i$, där socialgrupperingen "eftersom alternativ saknas" fortsatte att användas. ${ }^{36}$ Det skulle dröja mer än 30 år innan en ny stabil klasstaxonomi kom på plats - SCB:s Socioekonomiska indelning $(1982)^{37}$ - och i detta interregnum etablerades socialgruppstaxonomin till att bli en sorts standardvariabel i studiet av sociala skillnader, samtidigt som den ständigt var kritiserad som en ovetenskaplig kvarleva från det tidiga 1900-talet.

Svensk sociologi, etablerad som disciplin med filosofen Torgny T. Segerstedts (1908-1999) utnämning till professor 1947 i ämnet vid Uppsala universitet, tog inspiration från Amerika, med statistiska analyser som vetenskapligt ideal. ${ }^{38}$ En egenart utvecklades dock snabbt som en inhemsk tradition: socialgruppstaxonomin. I den första svenska avhandlingen i sociologi (1951), om gifta pars upplevelser av trivsel inom äktenskapet, kategoriserades paren efter socialgrupp, men utan förklaring varför denna indelning valts. ${ }^{39} \mathrm{I}$ de sociologiska handböckerna som gavs ut under 1950-talet återkom taxonomin om och om igen, exempelvis i sammanställningar av hur många från varje socialgrupp som bodde i en stadsdel, samband mellan

34 Torsten Husén, Begåvning och miljö: Studier i begåvningsutvecklingens och begåvningsurvalets psykologisk-pedagogiska och sociala problem (Stockholm: Geber, 1948).

35 Betänkande och förslag angående studentsociala stödåtgärder, 27-31. Även 1945 års studentberedning sammanställde statistik över studenternas sociala bakgrund med hjälp av socialgruppstaxonomin under samma tid som Studentsociala utredningen arbetade. Se SOU 1949:48, Studenternas sociala ursprung, betyg i studentexamen, vidare utbildning, yrkesval $m$. m.: En statistisk undersökning av 1930, 1937 och 1943 års studentårgångar (Stockholm: Iduns Tryckeriaktiebolag, Esselte AB, 1949).

36 Jörgen Westerståhl, ”Begreppet samhällsklass," Statsvetenskaplig Tidskrift 55, no. 4 (1952), 306.

37 Indelningen baseras på yrkesposition. I sin mest aggregerade form består den av grupperna: ej facklärda arbetare, facklärda arbetare, lägre tjänstemän, tjänstemän på mellannivå, högre tjänstemän, samt företagare. Se Statistiska Centralbyrån, "Socioekonomisk indelning (SEI)," Meddelanden $i$ samordningsfrågor 4 (1982).

38 Anna Larsson, Det moderna samhällets vetenskap: Om etableringen av sociologi i Sverige 1930-1955 (Diss. Umeå Universitet, 2001), 179-82.

39 Georg Karlsson, Adaptability and Communication in Marriage: A Swedish Predictive Study of Marital Satisfaction (Diss. Uppsala Universitet, 1951). Se också Edmund Dahlström, Trivsel i Söderort: Sociologisk undersökning i Hägerstensåsen och Hökmossen 1949-1950 (Stockholm: Esselte Aktiebolag, 1951), 61, se även 235. 
social bakgrund och religiositet, eller för att förstå vänskapsband. ${ }^{40}$ Sättet sociologer och andra samhällsvetare här konceptualiserade klass och samhällsstruktur sprang inte nödvändigtvis ur en ideologisk eller vetenskaplig övertygelse om att det bäst reflekterade samhället, det var istället ett pragmatiskt val efter vad som fanns att tillgå i form av utprövade statistiska klassifikationer, och den kunde som en standard möjliggöra jämförelser i tiden och mellan olika studieobjekt. ${ }^{41}$ En person som explicit tog ställning för socialgruppsindelningen var Gunnar Boalt, som 1954 skulle komma att utnämnas till Sveriges andra professor i sociologi, förlagd till Stockholms högskola: "Det är bekvämt att ta till en uppdelning av yrken i högre och lägre, som är klar och prövad. Använder jag den uppdelningen, har jag ibland möjlighet att jämföra mina värden med andra data" lärde Boalt ut i en av de första handböckerna för den nya sociologin. Om indelningen verkligen var dåligt anpassad för en studie, då skulle det märkas på resultaten, enligt honom. ${ }^{42}$ Likaså blev indelningen använd i en rad statliga utredningar från slutet av 1940-talet och framåt, och kom på det sättet att strukturera kunskapen om en mängd olika samhällsområden under efterkrigstiden: från vilka som gjorde abort, rekryteringen till officersutbildningen, försumliga försörjare, daghemsbarn, och läsvanor, bland många andra. ${ }^{43}$

Vanligare var öppen kritik gentemot taxonomin, bland annat för att den var missvisande gällande Sveriges samhällsstruktur. "Detta falska, föråldrade och ologiska system, som borde bannlysas i alla vetenskapliga framställningar, helst också i den politiska debatten" manade den konservative historieprofessorn Sten Carlsson i en av $S v D$ :s understreckare. ${ }^{44}$ Torgny T. Segerstedt var tveksam huruvida samhällsklasser och socialgrupper var verkliga sociologiska begrepp. I dagligt tal och bland partierna möttes man dagligen av klassbegrepp skrev han, "ordet klass har gått oss i blodet." Men enligt hans system var samhället egentligen uppbyggt av en mängd primärgrupper, kollektiv byggda på kommunikation ansikte mot ansikte med en gemensam normkälla. Varje försök att representera en klass, likt arbetarrörelsen gjorde, var falskt eftersom dess medlemmar aldrig skulle mötas i verkligheten. ${ }^{45}$

Ett mer intrikat argument mot socialgruppsindelningen var att valet av social indelning borde utprovas inför varje studie för att bäst passa fenomenet som skulle undersökas. Vad som skulle avgöra var vilken social variabel som gav högst statistiskt

40 Se exempelvis Edmund Dahlströms och Gunnar Boalts respektive bidrag i Sociologi (Stockholm: Forum, 1951); Berndt Gustafssons och Georg Karlssons respektive bidrag i Svensk samhällsstruktur $i$ sociologisk belysning, red. Edmund Dahlström (Stockholm: Svenska bokförlaget, 1959); Gunnar Boalt, Socialt beteende: Handbok i sociologi (Stockholm: Natur och kultur, 1961); Gunnar Boalt och Torsten Husén, Skolans psykologi (Stockholm: Almqvist \& Wiksell, 1964).

41 Så resonerar exempelvis Gösta Carlsson, "Samhällsklasser och social rörighet," i Svensk samhällsstruktur i sociologisk belysning, red. Edmund Dahlström (Stockholm: Svenska bokförlaget, 1959), 372.

42 Gunnar Boalt, "Status," i Sociologi (Stockholm: Forum, 1951), 33. Se också samma försvar i Gunnar Boalt, "Ståndscirkulation och invandring," Dagens Nyheter, 8 april, 1952.

43 SOU 1944:51, Betänkande i abortfrågan (Stockholm: K.L. Beckmans boktryckeri, 1944); 1946:38, Betänkande med förslag rörande officersutbildningen inom armén $m$. $m$ (Stockholm: Ivar Hæggströms boktryckeri A.B. 1946); SOU 1951:15, Daghem och förskolor: Betänkande om barnstugor och barntillsyn (Stockholm: Victor Petterssons bokindustriaktiebolag, 1951); 1952:23, Bokutredningen: Betänkande (Stockholm: Emil Kihlströms tryckeri A.B. 1952).

44 Sten Carlsson, ”Studenternas sociala ursprung," Svenska Dagbladet, 7 maj, 1952.

45 Torgny T. Segerstedt och Agne Lundquist, Människan i industrisamhället 2: Fritidsliv - samhällsliv (Stockholm: Studieförbundet samhälle och näringsliv, 1955), 255-71, citat 256. 
utslag i korrelation. "En gruppering som genomgående ger höga samband finns inte, och i den meningen finns heller icke några samhällsklasser", förklarade Jörgen Westerståhl. ${ }^{46}$ Vad som förnekades här var att det finns en totaliserande taxonomi medborgarna grupperas efter i alla sammanhang. Likaså uttryckte Torsten Husén att social status eller ställning i själva verket endast var ett uttryck för en grupps bedömning: en person kunde "ha mycket olika status beroende på vilken aspekt som anlägges." Egentligen borde samhällsforskare söka gradera status efter varje grupps egna värderingar: "Bland akademiker kan det vara den uppnådda akademiska examen som tenderar att bli måttstocken, bland affärsmän framgången i form av årlig inkomst, bland barn den fysiska styrkan, i skolan de betyg eleven erhåller etc." ${ }^{47}$ Husén föreställde sig alltså ett samhälle med en mängd sätt att värdera samhällsposition, och ifrågasatte om det överhuvudtaget var möjligt att konstruera en hierarkisk social skala som var densamma över ett helt samhälle. Men om man tog till en indelning behövde forskaren röra sig med så "rena variabler som möjligt". Granskade man valstatistikens gruppering närmre skulle man upptäcka att den inte byggde på "något enhetligt kriterium", enligt Husén, den var en oren korsning av många variabler och borde därför inte användas. ${ }^{48}$ En annan kritik Husén anlade mot socialgruppstaxonomin var att den höll kvar svenskarna i förlegade klassföreställningar. Möjligheten - skapad genom de nya skolreformerna - för alla som var lämpade att kunna erhålla högre utbildning öppnade upp för klassmedvetandets borttynande ${ }^{49}$ Detta var en artikulation för den optimistiska andan som fanns inom skolkretsar under 50- och 60-talen.

Men som vi sett fanns en ambivalens hos Husén. En sådan komplex taxonomi där varje grupps värderingar inräknades realiserades aldrig, istället tog han till en indelning ganska lik SCB:s, fast i fyra klasser. Huséns lansering av Siver Hallgrens egengjorda taxonomi slog dock aldrig igenom. När han refererade andras studier lyfte han upp socialgruppsstatistik för att visa på olika fenomen och samband. Ur hans installationsföreläsning 1953 som professor i pedagogik och pedagogisk psykologi vid Stockholms högskola reflekterade han över vikten av att använda rätt taxonomi, samt hur olika indelningars konstruktionsprinciper ledde till radikalt skilda utfall i undersökningar. Han tog exemplet två grannar på landsbygden, en lantbrukare och en folkskollärare, vars inkomst på ett ungefär var lika, samtidigt som folkskollärarens barn hade 20 gånger större chanser att gå vidare till högre utbildning. En indelning enbart efter ekonomi hade placerat dessa i samma klass och alltså dolt skillnaderna. Här fanns djupgående men mer svårfångade "socialpsykologiska faktorer" att räkna in enligt Husén: socialiserade livsförväntningar och hemmiljöns inställning till bildning. ${ }^{50}$ Sättet människor inplacerades i sociala kategorier, reduceringsarbetet $\mathrm{i}$ kvantifieringar, gav stora skillnader i hur samhället kunde beskrivas, från jämlikt till ytterst ojämlikt.

46 Westerståhl (1952), 307. Se också Edmund Dahlström, "Synpunkter på termen 'samhällsklass," Ekonomisk Tidskrift 54, no. 2 (1952).

47 Husén (1948), 37-38.

48 Husén (1948), 36.

49 Torsten Husén, ”Kan vi fortfarande tala om ett klassamhälle?," Folkuniversitetet 6, no. 4 (1955).

50 Torsten Husén, "Installationsföreläsning Stockholms högskola: Rekrytering och intagning av elever till högre läroanstalter Torsten Husén 18 oktober 1953." Finns tryckt i Torsten Husén, Vad har hänt med skolan? Perspektiv på skolreformerna (Stockholm: Verbum Gothia, 1987). 
Den politiska och mediala ojämlikhetsdebatten om högre utbildning fortsatte under andra halvan av 1900-talet att understödjas av socialgruppsstatistik, exempelvis i 1955 års universitetsutredning, 1957 års skolberedning, 1960 års gymnasieutredning samt 1968 års utbildningsutredning..$^{51}$ "Talet om socialgrupper har Statistiska centralbyrån gått ifrån men inte jag... Det är svårt att beskriva de problem som olika social bakgrund för med sig utan att använda socialgruppstermerna." Vi kan här förstå hur central socialgruppsindelningen blivit inom utbildningspolitiken genom utbildningsministern Ingvar Carlssons uttalande från 1970. ${ }^{22}$ Utöver detta började flertalet longitudinella akademiska undersökningar löpa parallellt från och med 60-talet: projektet Ungdom i Göteborg med centrum i Göteborgs pedagogiska institution samlade exempelvis sedan 1963 material om stadens skolelever, med IQtest, enkäter över yrkesval, trivsel och värderingar samt socialgruppsuppgifter över föräldrarna, resulterande i ett tiotal avhandlingar, rapporter och dussintals studentuppsatser under 60- och 70-talen. ${ }^{53}$ Västmanlandsundersökningen, styrd från Stockholms universitets pedagogiska institution, samlade data från alla i nionde årskullen i Västmanland 1965, också denna efter socialgruppstaxonomin. ${ }^{54}$ Dessa storskaliga projekt försökte alla förstå eleven och studenten i det nya välfärdssamhället. ${ }^{55}$

Jag har hittills undersökt socialgruppstaxonomin bland samhällsvetare och statliga utredare. Hur all denna kunskapsproduktion skulle tolkas var inget givet. Jag ska nu övergå till att undersöka denna kunskaps användning i den politiska debatten.

\section{Vem är rädd för socialgruppsindelningen? Politiska konflikter kring begåv- ning och samhällsstruktur}

Konservativa skribenter och politiker attackerade socialgruppsstatistiken på två sätt. Grundprincipen i taxonomin var en hierarkisering där arbetarklassen stod underst och den utbildade som en del av överklassen, socialgrupp I. Vissa försökte få bort denna överklasstämpel, exempelvis genom en debatt 1950 som genererade hög medial aktivitet med hundratals artiklar publicerade under samlingsbegreppet "medelklassens kris". ${ }^{6}$ Jag vill mena att en anledning varför en stor diskus-

51 SOU 1958:11, Reserverna för högre utbildning: Beräkningar och metoddiskussion (Stockholm: Esselte Aktiebolag, 1958); SOU 1960:42, Social- och personlighetspsykologiska faktorer i relation till skolans differentiering (Stockholm: Esselte Aktiebolag, 1958); SOU 1963:15, Vägen genom gymnasiet: Elevernas syn på valsituationer och studieformer (Stockholm: Ecklesiastikdepartementet, 1963); SOU 1971:61, Val av utbildning och yrke (Stockholm: Allmänna Förlaget, 1971).

52 Anna Lena Wik-Thorsell, "Kuratorer fick undvikande svar från Ingvar Carlsson om de skoltrötta eleverna," Svenska Dagbladet, 7 november, 1970.

53 Bengt-Erik Andersson, En beskrivning av forskningsgruppen kring Projekt UG (Ungdom i Göteborg) och dess verksamhet (Göteborg: Göteborg Universitet, 1970).

54 Se Lars Sundman, Socioekonomisk differentiering i grundskolan (Lund: Liber Läromedel/Gleerup, 1979), 72.

55 Se också Harald Swedners projekt vid sociologiska institutionen i Lund kartläggning av social segregering mellan stadsdelar och skolor genom socialgruppsindelningen: Harald Swedner och Gisela Edstrand, "Skolsegregation - visst finns den!," Kommunal Skoltidning 27, no. 4 (1969). "Individualstatistikprojektet" startade i sin tur upp 1961 vid pedagogiska institutionen i Stockholm för att följa över tjugotusen elevers betygsutveckling och yrkesval över en längre tid, med här med en taxonomi med sex yrkesklasser. Se Allan Svensson, Hembakgrund och prestationsnivå (Göteborg: Göteborg Universitet, 1972).

56 Debatten är undersökt av historikern Orsi Husz som ett sätt att skapa positiva symboliska värderingar av vissa yrkeskategorier i förväntan på framtida materiella resurser. Orsi Husz, "Att räkna värdighet. Privatekonomi och medelklasskultur vid mitten av 1900-talet," Scandia 79, no. 1 (2013). 
sion om medelklassens kris bröt ut vid denna tidpunkt ska ses mot fonden av den mediala utmålningen av universiteten som en odemokratisk kvarleva. $S v D$ placerade istället akademikern som en del av en alltmera utsatt medelklass. ${ }^{57}$ Inom den demokratiska diskurs som etablerades efter andra världskriget i fråga om ökade rättigheter för fler och fler att få studera vidare, ansågs klassifikationen överklass vara blamerande. Studentsociala utredningen hade medgivit att påståendet att akademiker tillhörde överklassen saknade materiell grund, men "en omprövning av den sociala rangskalan" kunde inte komma till stånd förrän den akademiska utbildningen öppnats upp för alla lämpade, menade de. ${ }^{58}$ Socialdemokratin kontrade i debatten med att framhålla att enligt socialgruppsindelningen tillhörde akademikern socialgrupp I. Högern försökte vinna väljare från medelklassen och hade "allt att vinna på en så diffus tolkning som möjligt av medelklassbegreppet." ${ }^{5}$

En andra argumentationslinje på $S v D$ :s sidor var huruvida det egentligen fanns någon begåvningsreserv. I en ledare framhölls att en vanlig position i debatten var att begåvningsreserven i folkdjupen var outtömlig, men nu hade antalet studenter stigit samtidigt som kunskapsnivån sjönk. Beräkningarna hade slagit fel. ${ }^{60}$ Språkprofessor Erik Wellander vidhöll att kunskaperna hos eleverna i läroverken försämrats efter tillströmningen av "missgynnade socialgrupper" vilka bar med sig en lägre bildningsstandard hemifrån. ${ }^{61}$ De högre skolorna "kunna aldrig i fråga om elevernas sociala ursprung bli något slags miniatyr av samhället i stort" var historieprofessorn Sten Carlssons slutsats. Hereditära, sociala och psykologiska faktorer spelade in i begåvningsfördelningen bland sociala skikt i samhället. ${ }^{62}$ I Svensk Tidskrift varnades likaså för att utgå från "att begåvningsurvalet skall vara exakt lika inom alla socialgrupper." 63

Inom Socialdemokraterna blev sättet att argumentera för ett politiskt förslag genom att först räkna upp socialgruppsstatistiken och uttrycka missnöje vanligt förekommande. ${ }^{64}$ Socialgruppsstatistiken blev snart också ett administrativt och politiskt verktyg för att överblicka framsteg i utbildningspolitiken såväl som för att justera utbildningsbudgetar. Statsstipendier till behövande studenter hade införts i blygsam skala vid ingången till andra världskriget. I kalkyler av Studentsociala utredningen om hur det statliga stipendieväsendet skulle byggas ut beräknades behovet av kommande finansiellt stöd för de olika socialgrupperna på universiteten. ${ }^{65}$

57 Osignerad artikel, "Spårvägskontrollör har 40000 kr:s läkares lön," Svenska Dagbladet, 17 januari, 1950. Bidragen i SvD samlades i boken Rättvisa åt medelklassen (Stockholm: Seelig, 1950).

58 Betänkande och förslag angående studentsociala stödåtgärder (1948), 20.

59 Hans Hagnell, "Svenska Dagbladet och medelklassen," Tiden 42, no. 4 (1950), 212.

60 Osignerad artikel, "Den kvalificerade arbetskraften," Svenska Dagbladet, 13 augusti, 1950.

61 Erik Wellander, "Nivån i Läroverken," Svenska Dagbladet, 20 juni, 1951.

62 Carlsson (1952).

63 Henrik Elmgren, "En demokratisk skola," Svensk Tidskrift 35 (1948), 343. Se också Arne Johansson, "Kravet på rättvisa," Svensk Linje 8, no. 3 (1949); Gunnar Hillerdal, "Studentsociala utredningen: angrepp och försvar," Liberal debatt 2, no. 1 (1949), 19.

64 Sveriges Socialdemokratiska Arbetareparti, Socialdemokratiska arbetarepartiets 21:a kongress 1960: Protokoll (Stockholm: Partiet, 1961), 369. Se även kongressen 1956 där flera talare hänvisade till socialgruppssiffror över rekryteringen till högre utbildning. Sveriges Socialdemokratiska Arbetareparti, Protokoll: Sveriges socialdemokratiska arbetarepartis 20:e kongress $i$ Stockholm 1956 (Stockholm: Partiet, 1956), 285-306.

65 Betänkande och förslag angående studentsociala stödåtgärder (1948), 162. 
Men detta var, kommenterade utbildningspropositionerna under 1950-talet, ett rörligt mål som ständigt behövde justeras precis eftersom den eftersökta riktlinjen att öka antalet studenter från socialgrupp III lyckades, och med det antalet i behov av stipendier - vad som beskrevs som en pågående "socialgruppsförskjutning" vid universiteten. ${ }^{66}$ "Vi är på väg bort från den snedvridna fördelningen av de studerande på olika socialgrupper", uttryckte Ragnar Edenman hoppfullt som ny ecklesiastikminister 1958. Av de nyinskrivna var 17 procent från socialgrupp III enligt hans beräkningar. ${ }^{67}$ Taxonomin möjliggjorde ett gemensamt ramverk för att artikulera och utvärdera framsteg för utbildningspolitiken som gjorde frågan om ojämlikhet politiskt och administrativt hanterbar och åskådligbar genom dessa siffor. Samhället och samhällsstrukturen tycktes nu förändringbar, de verkade i en ny sorts planeringsrationalitet med strävan att göra samhällsområden representativa för den föreställda befolkningsstrukturen i sin helhet.

Men inom arbetarrörelsen skapade diskussionerna om högre utbildning friktion. Sedan socialdemokratins början hade en av deras principer varit att omvärdera yrken och klasser, och ge kropparbetet samma status som andra sorters sysselsättning. ${ }^{68}$ Exempelvis framhöll riksdagsmannen Conrad Jonsson 1941 att lösningen inte var att skicka fler barn från arbetarklassen till lärdomsskolorna: det gällde istället att "reducera den överdrivna och kraftförslösande värderingen av den s.k. lärdomsskolan och att höja värderingen av yrkesskolorna." ${ }^{69}$ Arbetarrörelsens Bildningsförbunds ledare Gunnar Hirdman argumenterade i en skrift (1938) att det var positivt att arbetarklassens barn inte gick vidare till läroverken och universiteten. De skulle för det första inte trivas där utan var lyckligare av att stanna inom sin klass, men främst var det en "orättvis nytta" att begåvningar blev kvar och hjälpte de egna organisationerna istället för att förfrämligas från sitt ursprung. ${ }^{70}$

Den socialdemokratiskt dominerade 1946 års skolkommission underströk både vikten av att skapa lika tillgång till högre utbildning som att få till en jämvikt mellan hur "manuella" och "intellektuella" arbeten värderades: skolan borde försöka förmå vissa begåvningar att välja manuella yrken argumenterade de: annars kunde de "praktiska yrkena och de socialgrupper, som ägnade sig åt dem... bli föremål för en ödesdiger nedvärdering, en samhällsklyvning skulle uppstå och folkstyret komma i fara." ${ }^{71}$ Alva Myrdal hade under arbetes gång som ledamot i utredningen blivit allt mer oroad för en samhällsutveckling som kunde komma till följd av ett demokratiskt samhälle. Just precis skolans demokratisering hotade skapa "ett klassamhälle på

66 Proposition 1960/89, 13, 38.

67 Osignerad artikel, "Ny översikt görs av studenternas problem," Expressen, 19 maj, 1958.

68 Se exempelvis (1925) Ernst Wigforss, "Socialismen - dogm eller arbetshypotes?" i Kan dödläget brytas, red. Niklas Nåsander (Stockholm: Karneval, 2013).

69 Conrad Jonsson, "Utbildningsmöjligheternas demokratisering," i Skolan och folket: Anförande och diskussioner vid Sveriges socialdemokratiska ungdomsförbunds konferens i Stockholm den 26 och 27 september 1941 om skola och folk (Stockholm: Frihets Förlag, 1941), 118-19.

70 Gunnar Hirdman, Kulturell demokrati (Stockholm: ABF:s Centralbyrå, 1938). Se också Åke Isling, Kampen för och mot en demokratisk skola 1: Samhällsstruktur och skolorganisation (Stockholm: Sober, 1980), 220-24.

71 SOU 1948:27, 1946 års skolkommissions betänkande med förslag till riktlinjer för det svenska skolväsendets utveckling (Stockholm: Ivar Hæggströms boktryckeri A.B. 1948), 70. 
begåvningsgrundval.”72 Myrdal, som tidigare menat att de enskilda samhällsklasserna inte var bärare av särskilda anlag, argumenterade nu att klasserna över tid hotade få särskilda genetiska profiler. Det var en frestelse för arbetarrörelsen skrev hon att byta ut orden begåvade och obegåvade med termerna teoretisk och praktisk begåvning, två termer 1940 års skolutredning och 1946 års skolkommission arbetade med i syfte att värdera yrkesvägarna likadant. Många diskussioner hade kretsat kring dessa kategorier, något som tyder på hur stor vikt de lade på att finna nya samhälleliga sätt att värdera. ${ }^{73}$ Men uppdelningen var för enkel enligt Myrdal, dessa två begåvningsformer korsades på en rad sätt i skilda yrken, även i praktiska yrken krävdes ibland teoretisk begåvning och vice versa. Hon antydde att hela frågekomplexet borde tänkas om i grunden, bland annat genom att sluta högvärdera "onyttiga" och knappologiska kunskaper, och istället höja respekten för vetande som utgår från "konkreta ting och vår egen tids angelägenheter." Något som kunde ske genom en enhetsskola där eleverna inte delades upp efter begåvning, och där alla fick ta del av både teoretiska och praktiska undervisningsmoment. ${ }^{74}$

Den potentiella utarmningen av begåvning inom arbetarklassen förblev ett diskussionsämne. Ordförande för 1946 års skolkommission, Stellan Arvidsson, såg i mitten av 50-talet tillbaka på de förändringar han varit med om att genomföra: "På bred front håller socialgrupp III på att erövra realskolan.” Den ståndscirkulation som alltid pågått för enstaka individer hade blivit en massföreteelse - "väldiga fonder intelligens från arbetarklassen pumpas upp i högre samhällsskikt och förstärker dessa." Resultatet ledde mot att "Socialgrupp III utarmas på intelligens." I fjärran skymtade Arvidsson "en ödesdiger klyvning av vårt folk i ett överskikt, där begåvningarna samlats, och ett underskikt av medelmåttigt och lågt begåvade." ${ }^{\prime 7}$ Dessa diskussioner kring faran för en ny klasstruktur på meritokratisk grund fortsatte igenom 60-talet. ${ }^{76}$

I frågor rörande utbildningspolicy fortsatte socialgruppsstatistik mobiliseras i argumentationen. Bland annat väcktes diskussioner om studielön i början av 60-talet med argument att detta skulle få fler ur socialgrupp III att våga studera vidare. ${ }^{77} \mathrm{Ef}$ ter en utredning i frågan vände dock socialdemokratin, och dagens system med en bidragsdel och en lånedel infördes. Detta motiverades med att i nuläget vore studielön lika med "stora inkomstöverföringar till en redan privilegierad samhällsgrupp." Studier visade att det var mellan högstadiet och gymnasiet som socialgrupp 3 slogs ut, därför borde resurserna satsas i tidigare stadier. ${ }^{78}$ En utbyggd förskola lanserades i slutet av 60-talet som ett medel för att öka socialgrupp III:s chanser till högre utbildning senare i livet. ${ }^{79}$ En effekt av studier om social segregering mellan skolor var

72 Alva Myrdal, "Den inre skolreformens strategiska betydelse," Tiden 38, no. 4 (1946), 208.

73 Richardson (1983), 189-91, 384, 416

74 Myrdal (1946), 209.

75 Stellan Arvidson, "Skolreformen som socialreform," Tiden 48, no. 2 (1956), 93.

76 Joakim Landahl och Daniel Lövheim, "Varning för meritokratin: Den svenska receptionen av ett begrepp under 'det långa 68,'” i 1968 och pedagogiken, red. Anders Burman och Joakim Landahl (Huddinge: Södertörns högskola, 2020).

77 N.E. "Studielön," Tiden 54, no. 1 (1962); Osignerad artikel, "'Lösning på bredden’: Gör studielönen rättvis," Libertas 22, no. 3 (1963).

78 Osignerad artikel, ”Studiestödet och jämlikheten," Tiden 56, no. 1 (1964), 4.

79 Ingvar Carlsson, Jämlikhet $i$ utbildningen (Stockholm: Sveriges socialdemokratiska ungdomsförbund, 1970). 
att skolstyrelserna gavs i uppdrag i läroplanen för grundskolan 1969 att "verka för att klasserna anordnas så, att en så allsidig social sammansättning som möjligt erhålls." ${ }^{80}$

Vi kan från 70-talet se hur socialgruppstaxonomin blev produktiv på nya sätt: medverkade i att skapa nya begreppsliggöranden och verklighetsbeskrivningar. Optimism över möjligheter att kunna skapa ett jämställt samhälle genom utbildningsreformer skiftade till pessimism. ${ }^{81}$ Ett nytt fokus kom att läggas på en grupp kallade "skoltrötta", främst rekryterade ur socialgrupp III, vilka fått möjlighet till utbildning men som inte ville lära sig något. ${ }^{82}$ Torsten Husén reflekterade senare över hur skolforskningen under denna tid gått från eufori till krisstämning med insikten att den nya grundskolan och det nya gymnasiet inte hade jämnat ut utbildningsskillnaderna mellan socialgrupperna. Istället hade en "en pedagogisk underklass" uppkommit. ${ }^{83}$ På socialdemokraternas partikongress 1978 medgav tidigare skolminister Lena Hjelm-Wallén att de sociala skillnaderna endast stärkts mellan barnen efter alla år av socialdemokratisk skolpolitik. ${ }^{84}$ Under 80 -talet skulle skolpolitiken mer komma att betona skolans uppgift att ge alla grundläggande färdigheter. ${ }^{85}$

I nya rapporter över snedrekrytering sorterades studenter efter en socioekonomisk indelning skapad 1982 av SCB. Utbildningsministern under 80-talet, Bengt Göransson, använde sig av detta faktum för att göra gällande att det inte gick att veta om det blev mer eller mindre jämlikt jämfört med tidigare decennier: "de statistiska uppgifterna är svårtolkade, eftersom indelningen av befolkningen i socialgrupper har ändrats i olika undersökningar", argumenterade han. ${ }^{86}$ Med utfasningen av socialgruppsindelningen övergavs en hel föreställningsvärld.

\section{Avslutning}

Denna artikel har följt en klasstaxonomi mellan utbildningsforskning och den politiska och mediala idédebatten åren 1945-1960. Undersökningen är ett bidrag till att förstå klasskategoriers roll i efterkrigstidens utbildningsforskning, samt hur denna kunskapsproduktion skapade föreställningar om klass. Socialgruppsindelningen, ursprungligen konstruerad 1911 för SCB:s valstatistik, var en nyckelkomponent i konceptualiseringar som begåvningsreserven under efterkrigstiden, och genom

80 Skolöverstyrelsen, Läroplan för grundskolan: 1 Allmän del (Stockholm: Utbildningsförlaget, 1969), 17.

81 Bo Rothstein, Den socialdemokratiska staten: Reformer och förvaltning inom svensk arbetsmarknadsoch skolpolitik (Stockholm: Arkiv, 1986), 101.

82 Wik-Thorsell (1970); SOU 1974:53, Skolans arbetsmiljö: betänkande (Stockholm: Allmänna förlaget, 1974). Se också Karin Hadenius, Jämlikhet och frihet: Politiska mål för den svenska grundskolan (diss. Uppsala universitet, 1990), 304-306.

83 Torsten Husén, "Perspektiv på svensk skolforskning under 70-talet. Några reflexioner med anledning av Pedagogiska nämndens tioåriga verksamhet," i Grundskolan under 20 år: Från Pedagogiska nämndens utvärderingar (Stockholm: Liber/Utbildningsförlaget, 1982).

84 Sveriges Socialdemokratiska Arbetareparti, Protokoll: Sveriges socialdemokratiska arbetarepartis 27:e kongress, Tredje delen (Stockholm: Partiet, 1979), 897. Se liknande Gudrun Nordgren, "Får vi en bättre skola nu, Lena?" Aftonbladet, 29 februari, 1976.

85 Göran Bergström, Jämlikhet och kunskap: Debatter och reformstrategier i socialdemokratisk skolpolitik 1975-1990 (Stockholm: Symposion graduale, 1993), 218; Hadenius (1990), 307.

86 Lars Truedson, "Ökad social snedrekrytering oroar inte utbildningsminister," Svenska Dagbladet, 17 maj, 1989. 
samhällsvetenskaperna i allmänhet och utbildningsforskningen i synnerhet blev taxonomin som ett sätt att beskriva den svenska samhällsstrukturen vitt spridd. Ett statistiksociologiskt perspektiv i artikeln understryker det aktiva reduceringsarbete när något komplext som social position, status, samhällshierarkier, integreras till siffror. Detta möjliggör att fenomen kan jämföras och representeras. Taxonomin tillät för samhällsvetare, politiker och intresserade allmänheter att följa och utvärdera resultat av reformer i försök att komma tillrätta med den ojämlika rekryteringen till högre utbildning under efterkrigstiden. En orsak till socialgruppsindelningens mediala genomslag kan sägas vara dess pedagogiska enkelhet. Den blev efterhand inarbetad och välkänd bland allmänheter, politiker, och samhällsvetare, och därför lätt att ta sig till. Kunskap om socialgrupp III kunde också enkelt "översättas" och identifieras som arbetarklassen, och hade därför en stark intressent i form av socialdemokratin, som fick användning av den i valkampanjer, politisk strategi, och policyutformning.

Ett empiriskt resultat är att taxonomiska konflikter tilldrog sig kring socialgruppsindelningen. I tidigare forskning kring byråkratiska kategorier beskrivs de som ytterst stabila och svåra för utomstående att ifrågasätta när de väl kommit på plats. ${ }^{87}$ I denna artikel visas istället hur en klasstaxonomi, parallellt med att den fasas ut ur SCB för att vara ovetenskaplig, övertogs och brukades för en stor mängd studier inom samhällsvetenskaperna och statliga utredningar. Den blev en sorts standardindelning för att förstå och studera samhällsstrukturen inom ämnen som sociologi och pedagogik. Taxonomin var redan utprövad, enkel att använda, och viktigast av allt, gav jämförelsemöjligheter till andra studier. Samtidigt var flera samhällsvetare ytterst kritiska mot socialgruppsindelningen, framhöll den som godtyckligt konstruerad och missvisande. Den upprätthölls ofta, inte genom explicita ideologiska eller vetenskapliga försvar för dess förmåga att spegla klasstillhörigheter, utan i dess kraft att redan existera. Tolkningen av denna utbildningsforskning var inte given: konservativa debattörer ifrågasatte huruvida det egentligen fanns någon begåvningsreserv bland de lägre socialgrupperna, och kritiserade socialgruppsindelningen för att felaktigt återge samhället. De argumenterade för att akademiker inte alls var del av någon priviligierad överklass. Inom socialdemokratin orsakade ett ökat fokus på att få fler arbetare att läsa vidare spänning, då detta av vissa menades kunna utarma arbetarklassen på begåvning.

87 Hacking (1990); Porter (1995); Bowker och Star (1999). 


\section{Referenser}

Arkiv

"P.M. angående den i de valstatistiska berättelserna använda fördelningen på yrkesoch socialgrupper." Handlingar ordnade efter ämne: Instruktioner, koder, PM. MM., Valstatistikens ämbetsarkiv 1872-1957, Statistiska Centralbyrån, Riksarkivet.

\section{Tryckta källor och litteratur}

Andersson, Bengt-Erik. En beskrivning av forskningsgruppen kring Projekt UG (Ungdom $i$ Göteborg) och dess verksamhet. Göteborg: Göteborg Universitet, 1970.

Arvidson, Stella. "Skolreformen som socialreform." Tiden 48, no. 2 (1956).

Bergström, Göran. Jämlikhet och kunskap: Debatter och reformstrategier $i$ socialdemokratisk skolpolitik 1975-1990. Stockholm: Symposion graduale, 1993.

Boalt, Gunnar. Skolutbildning och skolresultat för barn ur olika samhällsgrupper $i$ Stockholm. Stockholm: Nordstedt, 1947.

Boalt, Gunnar. "Status." I Sociologi. Stockholm: Forum, 1951.

Boalt, Gunnar. "Ståndscirkulation och invandring." Dagens Nyheter, 8 april, 1952.

Boalt, Gunnar. Socialt beteende: Handbok i sociologi. Stockholm: Natur och kultur, 1961.

Boalt, Gunnar, och Torsten Husén. Skolans psykologi. Stockholm: Almqvist \& Wiksell, 1964.

Bowker, Geoffrey C, och Susan Leigh Star. Sorting Things Out: Classification and its Consequences. Cambridge, Mass.: MIT Press, cop. 1999.

Carls, Lina. Våp eller nucka? Kvinnors högre studier och genusdiskursen 1930-1970. Lund: Nordic Academic Press, 2004.

Carlsson, Gösta. "Samhällsklasser och social rörighet." I Svensk samhällsstruktur $i$ sociologisk belysning, red. Edmund Dahlström. Stockholm: Svenska bokförlaget, 1959.

Carlsson, Gösta, Robert Eriksson, Christina Löfwall och Bo Wärneryd. "Socio-ekonomiska grupperingar." Statistisk Tidskrift 12, no. 5 (1974).

Carlsson, Ingvar. Jämlikhet i utbildningen. Stockholm: Sveriges socialdemokratiska ungdomsförbund, 1970.

Carlsson, Sten. "Studenternas sociala ursprung." Svenska Dagbladet, 7 maj, 1952.

Carson, John. The Measure of Merit: Talents, Intelligence, and Inequality in the French and American Republics, 1750-1940. Princeton: Princeton University Press, cop. 2007.

Crompton, Rosemary. Class and Stratification: An Introduction to Current Debates (Malden, MA.: Blackwell, cop., 1998).

Dahlström, Edmund. Trivsel i Söderort: Sociologisk undersökning i Hägerstensåsen och Hökmossen 1949-1950. Stockholm: Esselte Aktiebolag, 1951.

Dahlström, Edmund. "Synpunkter på termen 'samhällsklass"' Ekonomisk Tidskrift 54, no. 2 (1952).

Dahlström, Edmund. "Stadssociologi." I Sociologi. Stockholm: Forum, 1951.

Diaz-Bone, Rainer, och Emmanuel Didier. "Introduction: The Sociology of Quantification - Perspectives on an Emerging Field in the Social Sciences." Historical Social Research / Historische Sozialforschung 41, no. 2 (2016). 
Eckerberg, Per. "Utbildningens demokratisering." Tiden 40, no. 10 (1948).

Elmgren, Henrik. "En demokratisk skola." Svensk Tidskrift 35 (1948).

Fagerström, Allan. ”De odemokratiska akademierna", Aftonbladet, 20 mars, 1948.

Fitzpatrick, Sheila. "Ascribing Class: The Construction of Social Identity in Soviet Russia." Journal of Modern History 65, no. 4 1993).

Grafström, Lars. "Staten, akademikerna och friheten." Liberal Debatt 1, no. 1 (1948).

Gustafsson, Berndt. "Det religiösa livet”. I Svensk samhällsstruktur i sociologisk belysning, red. Edmund Dahlström. Stockholm: Svenska bokförlaget, 1959.

Hacking, Ian. The Taming of Chance. Cambridge: Cambridge University Press, cop., 1990.

Hadenius, Karin. Jämlikhet och frihet: Politiska mål för den svenska grundskolan. Diss. Uppsala universitet, 1990.

Hagnell, Hans. "Svenska Dagbladet och medelklassen." Tiden 42, no. 4 (1950).

Hallgren, Siver. "Intelligens och social miljö.” I Studier i människokunskap tillägnade John Landquist den 3 december 1946. Lund: Gleerup, 1946.

Hammarström, Ingrid. "I stället för Långtidsprogram: Kring studentsociala utredningen." Libertas 9, no. 1 (1949).

Hillerdal, Gunnar. "Studentsociala utredningen: angrepp och försvar." Liberal debatt 2, no. 1 (1949).

Hirdman, Gunnar. Kulturell demokrati. Stockholm: ABF:s centralbyrå, 1938.

Holgersson, Ulrika. Klass: Feministiska och kulturanalytiska perspektiv. Lund: Studentlitteratur, 2011.

Husén, Torsten. "Intelligenskrav på olika skolutbildningsstadier: Några resultat från grupptestningar av en årsklass värnpliktiga." Skola och Samhälle 27, (1946).

Husén, Torsten. "Begåvningsurvalet och de högre skolorna." Sydsvenska Dagbladet, 11 maj, 1946.

Husén, Torsten. Begåvning och miljö: Studier i begåvningsutvecklingens och begåvningsurvalets psykologisk-pedagogiska och sociala problem. Stockholm: Geber, 1948.

Husén, Torsten. "Kan vi fortfarande tala om ett klassamhälle?" Folkuniversitetet 6, no. 4 (1955).

Husén, Torsten. En obotlig akademiker: En professors memoarer (Stockholm: Natur och kultur, 1981).

Husén, Torsten. ”Perspektiv på svensk skolforskning under 70-talet. Några reflexioner med anledning av Pedagogiska nämndens tioåriga verksamhet." I Grundskolan under 20 år: Från Pedagogiska nämndens utvärderingar. Stockholm: Liber/ Utbildningsförlaget, 1982.

Husén, Torsten. Vad har hänt med skolan? Perspektiv på skolreformerna. Stockholm: Verbum Gothia, 1987.

Husén, Torsten, och Kjell Härnqvist. Begåvningsreserven: En återblick på ett halvsekels forskning och debatt. Uppsala: Föreningen för svensk undervisningshistoria, 2000.

Husz, Orsi. "Att räkna värdighet. Privatekonomi och medelklasskultur vid mitten av 1900-talet." Scandia 79, no. 1 (2013).

Isling, Åke. Kampen för och mot en demokratisk skola 1: Samhällsstruktur och skolorganisation. Stockholm: Sober, 1980.

Johansson, Arne. "Kravet på rättvisa." Svensk Linje 8, no. 3 (1949). 
Jonsson, Conrad. "Utbildningsmöjligheternas demokratisering." I Skolan och folket: Anförande och diskussioner vid Sveriges socialdemokratiska ungdomsförbunds konferens i Stockholm den 26 och 27 september 1941 om skola och folk. Stockholm: Frihets Förlag, 1941.

Joyce, Patrick. Visions of the people: Industrial England and the question of class, 1848-1914. Cambridge: Cambridge University Press, 1991.

Karlsson, Georg. Adaptability and Communication in Marriage: A Swedish Predictive Study of Marital Satisfaction. Diss. Uppsala universitet, 1951.

Karlsson, Georg. "Familjen." I Svensk samhällsstruktur i sociologisk belysning, red. Edmund Dahlström. Stockholm: Svenska bokförlaget, 1959.

Landahl, Joakim, och Daniel Lövheim. "Varning för meritokratin: Den svenska receptionen av ett begrepp under 'det långa 68"' I 1968 och pedagogiken, red. Anders Burman och Joakim Landahl. Huddinge: Södertörns högskola, 2020.

Larsson, Anna. Det moderna samhällets vetenskap: Om etableringen av sociologi $i$ Sverige 1930-1955. Diss. Umeå Universitet, 2001.

Lawrence, Jon. "Social-Science Encounters and the Negotiation of Difference in early 1960s England." History Workshop Journal 77, no. 1 (2014).

Lövheim, Daniel. Naturvetarna, ingenjörerna och valfrihetens samhälle: Rekrytering till teknik och naturvetenskap under svensk efterkrigstid. Lund: Nordic Academic Press, 2016.

Markusson Winkvist, Hanna. "Perspektiv på begåvningsreserven." Lychnos (2014).

Myrdal, Alva. "Den inre skolreformens strategiska betydelse." Tiden 38, no. 4 (1946). N.E. "Studielön." Tiden 54, no. 1 (1962).

Nelson Espeland, Wendy, och Mitchell L. Stevens. "Commensuration as a Social Process." Annual Review of Sociology 24, no. 1 (1998).

Nordgren, Gudrun. "Får vi en bättre skola nu, Lena ?" Aftonbladet, 29 februari, 1976.

Norman, Nils. "Demokratiseringen av de akademiska yrkena." Tiden 39, no. 9 (1947).

Nyman, Alf. Bildning, elit, massa: Sju kulturpolitiska kapitel. Stockholm: Hugo Gebers, 1946.

Osignerad artikel. "Studenterna få ofta biinkomster under studierna." Dagens Nyheter, 27 december, 1933.

Osignerad artikel. "Fler intellektuella i samhällets tjänst." Aftonbladet, 14 november, 1935.

Osignerad artikel. "De intellektuellas yrkesproblem." Svenska Dagbladet, 15 november, 1935.

Osignerad artikel. "Sverige kan producera ytterligare 8.000 studenter pr år." Aftonbladet, 17 mars, 1948a.

Osignerad artikel. "De rikas universitet." Arbetartidningen, 22 oktober, 1948.

Osignerad artikel. "Universiteten öppnas." Aftonbladet, 5 november, 1948b.

Osignerad artikel. "Vår begåvningsreserv måste utnyttjas för högre studier." Svenska Dagbladet, 6 november, 1948.

Osignerad artikel. "Var 4:e student... Begåvningsreserven ur lägsta socialgruppen bör släppas fram till universitetsbildning." Dagens Nyheter, 6 november, 1948.

Osignerad artikel. "Spårvägskontrollör har 40000 kr:s läkares lön." Svenska Dagbladet, 17 januari, 1950.

Osignerad artikel. "Den kvalificerade arbetskraften." Svenska Dagbladet, 13 augusti, 1950. 
Osignerad artikel. "Ny översikt görs av studenternas problem.” Expressen, 19 maj, 1958.

Osignerad artikel. "'Lösning på bredden': Gör studielönen rättvis." Libertas 22, no. 3 (1963).

Osignerad artikel. "Studiestödet och jämlikheten." Tiden 56, no. 1 (1964).

Premfors, Rune. Svensk forskningspolitik. Lund: Studentlitteratur, 1986.

Porter, Jim. 'A 'Precious Minority': Constructing the 'Gifted' and 'Academically Talented' Student in the Era of Brown v. Board of Education and the National Defense Education Act." Isis 108, no. 3 (2017).

Porter, Theodore. Trust in Numbers: The Pursuit of Objectivity in Science and Public Life. Princeton: Princeton University Press, 1995.

Qvarsebo, Jonas. "Fabricating and Governing the Swedish School Pupil: The Swedish Post-War School Reform and Changing Discourses of Discipline and Behaviour." Nordic Journal of Educational History 5, no. 2 (2018).

Renwick, Chris. "Eugenics, Population Research, and Social Mobility Studies in Early and Mid-Twentieth-Century Britain." The Historical Journal 59, no. 3 (2016).

Renwick, Chris. "Movement, Space and Social Mobility in early and mid-Twentieth-Century Britain.” Cultural and Social History 16, no. 1 (2019).

Richardson, Gunnar. Svensk skolpolitik 1940-1945: Idéer och realiteter i pedagogisk debatt och politiskt handlande. Stockholm: Liber Förlag, 1978.

Richardson, Gunnar. Drömmen om en ny skola: Idéer och realiteter i svensk skolpolitik 1945-1950. Stockholm: Liber/Allmänna förlaget, 1983.

Riksdagstryck, Proposition 1960/89.

Rothstein, Bo. Den socialdemokratiska staten: Reformer och förvaltning inom svensk arbetsmarknads- och skolpolitik. Stockholm: Arkiv, 1986.

Savage, Mike. Identities and Social Change in Britain since 1940: The Politics of Method. Oxford: Oxford University Press, 2010.

Segerstedt, Torgny T., och Agne Lundquist. Människan i industrisamhället 2: Fritidsliv - samhällsliv. Stockholm: Studieförbundet samhälle och näringsliv, 1955.

Skolöverstyrelsen. Läroplan för grundskolan: 1 Allmän del. Stockholm: Utbildningsförlaget, 1969.

SOU 1936:34. Utredning rörande de svenska universitets- och högskolestudenternas sociala och ekonomiska förhållanden: Bilaga till Betänkande med undersökningar och förslag $i$ anledning av tillströmningen till de intellektuella yrkena. Stockholm: Håkan Ohlssons boktryckeri, 1936.

SOU 1944:51. Betänkande i abortfrågan. Stockholm: K.L. Beckmans boktryckeri, 1944.

SOU 1946:38. Betänkande med förslag rörande officersutbildningen inom armén $m$. m. Stockholm: Ivar Hæggströms boktryckeri A.B. 1946.

SOU 1948:27. 1946 års skolkommissions betänkande med förslag till riktlinjer för det svenska skolväsendets utveckling. Stockholm: Ivar Hæggströms boktryckeri A.B. 1948.

SOU 1948:42. Betänkande och förslag angående studentsociala stödåtgärder. Stockholm: Katalog och tidskriftstryck, 1948.

SOU 1949:48. Studenternas sociala ursprung, betyg $i$ studentexamen, vidare utbildning, yrkesval m. m.: En statistisk undersökning av 1930, 1937 och 1943 års studentårgångar. Stockholm: Iduns Tryckeriaktiebolag, Esselte AB, 1949. 
SOU 1951:15. Daghem och förskolor: Betänkande om barnstugor och barntillsyn. Stockholm: Victor Petterssons bokindustriaktiebolag, 1951.

SOU 1952:23. Bokutredningen: Betänkande. Stockholm: Emil Kihlströms tryckeri A.B. 1952.

SOU 1958:11. Reserverna för högre utbildning: Beräkningar och metoddiskussion. Stockholm: Esselte Aktiebolag, 1958.

SOU 1960:42. Social- och personlighetspsykologiska faktorer i relation till skolans differentiering. Stockholm: Esselte Aktiebolag, 1958.

SOU 1963:15. Vägen genom gymnasiet: Elevernas syn på valsituationer och studieformer. Stockholm: Ecklesiastikdepartementet, 1963.

SOU 1971:61. Val av utbildning och yrke. Stockholm: Allmänna Förlaget, 1971.

SOU 1974:53. Skolans arbetsmiljö: Betänkande. Stockholm: Allmänna förlaget, 1974.

Statistiska Centralbyrån. Riksdagsmannavalen åren 1908-1911. Stockholm: Statistiska Centralbyrån, 1912,

Statistiska Centralbyrån. Riksdagsmannavalen åren 1949-1952. Stockholm: Statistiska Centralbyrån, 1953.

Statistiska Centralbyrån. Sociala grupper i svensk statistik: Ett förslag framlagt av en av Statistiska centralbyrån tillsatt arbetsgrupp. Stockholm: Statistiska Centralbyrån, 1967.

Statistiska Centralbyrån. "Socioekonomisk indelning (SEI)." Meddelanden i samordningsfrågor 4 (1982).

Stedman Jones, Gareth. Languages of Class: Studies in English Working Class History, 1832-1982. Cambridge: Cambridge University Press, 1984.

Sundman, Lars. Socioekonomisk differentiering i grundskolan. Lund: Liber Läromedel/Gleerup, 1979.

Svenska Dagbladet. Rättvisa åt medelklassen. Stockholm: Seelig, 1950.

Svensson, Allan. Hembakgrund och prestationsnivå. Göteborg: Göteborg Universitet, 1972.

Swedner, Harald, och Gisela Edstrand. "Skolsegregation - visst finns den!" Kommunal Skoltidning 27, no. 4 (1969).

Sveriges Socialdemokratiska Arbetareparti. Protokoll, Sveriges socialdemokratiska arbetarpartis 18:e kongress i sth. 1948, 9-14 maj. Stockholm: Partiet, 1948.

Sveriges Socialdemokratiska Arbetareparti. Protokoll: Sveriges socialdemokratiska arbetarepartis 20:e kongress i Stockholm 1956. Stockholm: Partiet, 1956.

Sveriges Socialdemokratiska Arbetareparti. Socialdemokratiska arbetarpartiets 21:a kongress 1960: Protokoll. Stockholm: Partiet, 1961.

Sveriges Socialdemokratiska Arbetareparti. Protokoll: Sveriges socialdemokratiska arbetarepartis 27:e kongress, Tredje delen. Stockholm: Partiet, 1979.

Truedson, Lars. "Ökad social snedrekrytering oroar inte utbildningsminister." Svenska Dagbladet, 17 maj, 1989.

Wahlund, Sten. "Demokrati och utbildning." Social årsbok (1942).

Waldow, Floran. Utbildningspolitik, ekonomi och internationella utbildningstrender $i$ Sverige 1930-2000. Stockholm: Stockholms universitets förlag, 2008.

Wellander, Erik. "Det nya gymnasiets bildningsvärde." Svenska Dagbladet, 20 juli, 1932.

Wellander, Erik. ”Nivån i Läroverken," Svenska Dagbladet, 20 juni, 1951.

Westerståhl, Jörgen. "Demokratins skola." Tiden 33, no. 8 (1941). 
Westerståhl, Jörgen. "Begreppet samhällsklass." Statsvetenskaplig Tidskrift 55, no. 4 (1952).

Wigforss, Ernst. "Socialismen - dogm eller arbetshypotes?" I Kan dödläget brytas, red. Niklas Nåsander. Stockholm: Karneval, 2013.

Wik-Thorsell, Anna Lena. "Kuratorer fick undvikande svar från Ingvar Carlsson om de skoltrötta eleverna." Svenska Dagbladet, 7 november, 1970.

Wooldridge, Adrian. Measuring the mind: Education and psychology in England, $c$. 1860 - c. 1990. Cambridge: Cambridge University Press, cop., 1994.

Östling, Johan. Nazismens sensmoral: Svenska erfarenheter i andra världskrigets efterdyning. Stockholm: Atlantis, 2008. 